\title{
Penerapan Model PJBL Untuk Meningkatkan Keterampilan Proses dan Hasil Belajar Matematika Materi Bangun Ruang Sisi Datar Kelas VIII C SMP Negeri 4 Sumbang Semester 2 Tahun Pelajaran 2016/2017
}

\author{
Theresia Warsini \\ SMP N. 4 Sumbang
}

\begin{abstract}
ABSTRAK
Hasil belajar matematika di SMPN 4 Sumbang masih rendah. Hal ini disebabkan oleh faktor siswa kurang aktif, malas, dan cepat bosan, walaupun guru sudah berusaha membangkitkan minat belajar siswa, namun siswa masih kurang bersemangat untuk mempelajari matematika. Oleh karena itu perlu dilakukan upaya meningkatkan hasil belajar sehingga peneliti menerapkan model PjBL (Projek Based Learning) untuk meningkatkan keterampilan proses dan hasil belajar matematika materi bangun ruang sisi datar. Tujuan penelitian yang ingin dicapai adalah untuk mengetahui apakah pembelajaran model $P j B L$ dapat meningkatkan keterampilan proses dan hasil belajar matematika materi bangun ruang sisi datar. Penelitian ini merupakan Penelitian Tindakan Kelas. Perangkat pembelajaran, yaitu Silabus, RPP, bahan ajar, dan LKS. Sedangkan instrumen penelitian adalah tes uraian dan lembar observasi. Subjek penelitian adalah siswa kelas VIII C SMP N 4 Sumbang sebanyak 22 siswa. Penelitian dilaksanakan pada bulan Pebruari sampai dengan bulan Juni 2017. Subjek dan waktu penelitian tersebut dipilih karena peneliti mengajar di kelas tersebut dan waktu pelaksanaan disesuaikan dengan jadwal pelajaran. Prosedur penelitian dimulai dengan identifikasi masalah, perencanaan tindakan, pelaksanaan tindakan dan pengamatan, serta analisis dan refleksi. Hasil penelitian telah mampu menjawab perumusan masalah, mencapai tujuan penelitian dan membuktikan hipotesis penelitian yaitu penerapan pembelajaran model $P j B L$ dapat meningkatkan keterampilan proses dan hasil belajar matematika materi bangun ruang sisi datar siswa kelas VIII C SMP N 4 Sumbang tahun pelajaran 2016/2017. Keadaan tersebut dibuktikan oleh hasil siklus I siswa yang sangat terampil sebanyak $18 \%$, siklus II sebanyak $45 \%$ dan siklus III sebanyak $55 \%$. Hasil belajar siswa rata-rata 63,64 pada siklus I, 68,73 pada siklus II, dan meningkat lagi menjadi 75,27 pada akhir siklus III. Dari hasil tersebut disarankan sebaiknya guru mengembangkan model pembelajaran $P j B L$ pada materi yang akan disampaikan berikutnya agar dapat meningkatkan hasil belajar siswa. Sedangkan siswa disarankan untuk meningkatkan keterampilan proses pada saat pembelajaran dan lebih mempersiapkan diri sebelum proses pembelajaran dimulai.
\end{abstract}

Kata kunci: PjBL, keterampilan proses, hasil belajar

\begin{abstract}
The results of learning mathematics at SMPN 4 Sumbang are still low. This is caused by the factors of students who are less active, lazy, and easily bored, while teachers who have difficulty learning students, but students who do not like to learn mathematics. Therefore it is necessary to improve learning outcomes so that researchers apply the PjBL (Project Based Learning) model to enhance the process skills and mathematics learning outcomes of flat side space material. The research objective to be achieved is to find out whether the PjBL learning model can improve the learning process and the learning outcomes of mathematics in flat side space. This research is a Classroom Action Research. Learning tools, namely syllabus, lesson plans, teaching materials, and worksheets. While the research instrument is the description test and observation sheet. The subjects of the research were the students of class VIII C of SMP N 4 Sumbang with 22 students. The study was conducted in February through June 2017. The subject and time of the study were chosen because the researcher taught in the class, and the implementation time was adjusted to the lesson schedule. The research procedure begins with a discussion of the problem, planning of the action, implementing the action and observation, as well as analysis and reflection. The results of research that can answer the problem formulation achieve research objectives and prove research hypotheses about the application of the PjBL learning model can improve the process skills and learning outcomes of mathematics material in the scope of class VIII C students of SMP N 4 Sumbang 2016/2017 school year. This situation is proven by the results of the first cycle of highly competent students as much as $18 \%$, cycle II as much as $45 \%$ and cycles III as much as 55\%. Student learning outcomes on average 63.64 in the first cycle, 68.73 in the second cycle, and increased again to 75.27 at the end of the third cycle. From these results, it was agreed by the teacher to develop the PjBL learning model in the material that would be presented later to
\end{abstract}


improve student learning outcomes. In contrast, students appreciate enhancing the learning process when learning and better prepare themselves before the learning process begins.

Key words: PjBL, process skills, learning outcomes

\section{Pendahuluan}

Pendidikan merupakan aspek terpenting dalam upaya pemberdayaan manusia. Melalui pendidikan, pengembangan potensi, kepribadian, kecerdasan, ketrampilan serta akhlak mulia siswa dapat dibentuk dan diarahkan. Sistem pendidikan dewasa ini telah mengalami kemajuan yang sangat pesat. Berbagai cara telah dikenalkan dan digunakan dalam proses pembelajaran dengan harapan pengajaran guru akan lebih menarik dan lebih bermakna bagi murid. Menurut Mudjiono (2013:141) keterampilan proses memberikan kesempatan seluas-luasnya bagi siswa untuk mengamati, menggolongkan, menafsirkan, meramalkan, menerapkan, merencanakan penelitian, mengomunikasikan hasil yang diperoleh. Dengan keterampilan proses kemampuan siswa dalam mengelola dan memperoleh ilmu selama kegiatan belajar mengajar dapat ditingkatkan.

Keterampilan proses merupakan bagian yang tidak terpisahkan dalam rangka meningkatkan kualitas proses dan hasil pembelajaran matematika. Selain itu, keterampilan proses akan memudahkan siswa menyelesaikan permasalahan secara logis dan rasional serta dapat meningkatkan kemampuan menganalisis suatu informasi maupun kebenaran suatu pernyataan yang bermanfaat dalam kehidupan sehari-hari. Melalui penilaian keterampilan proses, guru mampu mendeteksi faktor penghambat siswa dalam menyelesaikan dan menghadapi suatu permasalahan pada saat proses pembelajaran matematika serta mampu memperbaiki dan meningkatkan kualitas proses belajar pada siswa. Apabila keterampilan proses siswa dapat diperbaiki maka akan berdampak pada peningkatan hasil belajar siswa.

Pada kenyataannya di kelas VIII C SMP 4 Sumbang ditemukan 4 kondisi yang tidak mendukung dalam proses pembelajaran matematika. Kondisi pertama, keterampilan proses siswa rendah dalam proses pembelajaran matematika. Hal ini terlihat pada saat kegiatan pembelajaran, siswa jarang melakukan beberapa keterampilan yang dilatihkan dalam keterampilan proses, yaitu merumuskan masalah, merencanakan percobaan, melakukan percobaan, mengamati percobaan, mengisi tabel data, menganalisis hasil percobaan, menyimpulkan dan mengomunikasikan hasil percobaan serta menerapkan konsep.

Kondisi kedua, proses belajar mengajar berorientasi pada teacher centered (berpusat pada guru). Guru menjelaskan materi kemudian siswa mengerjakan soal-soal latihan yang ada pada buku ajar siswa sehingga kemampuan dan potensi siswa yang beragam belum dikembangkan secara maksimal.

Kondisi ketiga, sikap ilmiah yaitu sikap ingin tahu, sikap penemuan, kreativitas, dan sikap ketekunan. belum ditunjukkan siswa saat proses pembelajaran matematika. Kondisi keempat sikap peka terhadap lingkungan sekitar pun belum ditunjukkan oleh siswa.

Apabila permasalahan ini tidak segera diselesaikan maka akan berdampak pada proses dan hasil belajar siswa. Berdasarkan temuan-temuan selama proses pembelajaran tersebut, maka peneliti menggunakan model Project Based Learning (PjBL) yang dapat meningkatkan keterampilan proses, menghasilkan sebuah produk, dan meningkatkan hasil belajar.

Morgan (Dalyono, 2003:211) mengatakan belajar adalah setiap perubahan yang relatif menetap dalam tingkah laku yang terjadi sebagai suatu hasil dari latihan atau pengalaman. Hudoyo (2002:21) mendefinisikan belajar sebagai perubahan dalam perbuatan melalui 
aktivitas, praktek dan pengalaman. Pembelajaran adalah upaya untuk menciptakan iklim dan pelayanan terhadap kemampuan, potensi, minat, bakat dan kebutuhan peserta didik yang beragam agar terjadi interaksi optimal antara guru dengan siswa serta antara siswa dengan siswa (Suyitno, 2004:1).

Usaha guru dalam pembelajaran matematika memerlukan konteks dan situasi yang berbedabeda, sehingga guru perlu upaya sebagai berikut (Depdiknas, 2003:6).

1. Menyediakan dan menggunakan berbagai alat peraga atau media pembelajaran yang menarik perhatian siswa.

2. Memberikan kesempatan belajar matematika di berbagai tempat dan keadaan.

3. Memberikan kesempatan menggunakan metematika untuk berbagai keperluan.

4. Mengembangkan sikap menggunakan matematika sebagai alat untuk memecahkan matematika baik di sekolah maupun di rumah.

5. Menghargai sumbangan tradisi, budaya dan seni di dalam pengembangan matematika.

6. Membantu siswa menilai sendiri kegiatan matematikanya.

Model PjBL menurut Trianto (2014:42) adalah pendekatan pembelajaran yang inovatif, yang menekankan belajar kontekstual melalui kegiatan-kegiatan yang kompleks. Menurut Wena (2014:144) model pembelajaran $P j B L$ adalah model pembelajaran yang memberikan kesempatan kepada guru untuk mengelola pembelajaran dikelas dengan melibatkan kerja proyek yang memuat tugas-tugas kompleks berdasarkan permasalahan yang sangat menantang dan menuntun siswa untuk merancang, memecahkan masalah, membuat keputusan, melakukan kegiatan investigasi, serta memberikan kesempatan siswa untuk bekerja secara mandiri. Hasil penelitian yang dilakukan Ekaputri (2012) menunjukan bahwa pembelajaran dengan metode $P j B L$ dengan strategi team teaching mampu meningkatkan motivasi, keaktifan, dan hasil belajar siswa.

Langkah-langkah model pembelajaran PjBL adalah sebagai berikut, Rais (2010:8-9).

1. Membuka pelajaran dengan suatu pertanyaan menantang (start with the big question).

2. Merencanakan proyek (design a plan for the project).

3. Menyusun jadwal aktivitas (create a schedule).

4. Mengawasi jalannya proyek (monitor the students and the progress of the project).

5. Penilaian terhadap produk yang dihasilkan (assess the outcome).

6. Evaluasi (evaluate the experience)

Pada akhir proses pembelajaran, guru dan siswa melakukan refleksi terhadap aktivitas dan hasil proyek yang sudah dijalankan. Proses refleksi dilakukan baik secara individu maupun kelompok. Pada tahap ini, siswa diminta untuk mengungkapkan perasaan dan pengalamannya selama menyelesaikan proyek.

Berdasarkan permasalahan di atas, tujuan penelitian ini adalah sebagai berikut. (1) Untuk mengetahui keterampilan proses siswa kelas VIII C SMP Negeri 4 Sumbang tahun pelajaran 2016/2017 dalam belajar materi bangun ruang sisi datar melalui model PjBL; dan 2) Untuk mengetahui hasil belajar belajar siswa kelas VIII C SMP Negeri 4 Sumbang tahun pelajaran 2016/2017 pada materi bangun ruang sisi datar melalui model PjBL. 


\section{Metode Penelitian}

Desain penelitian yang digunakan adalah penelitian tindakan kelas. Penelitian tindakan kelas ini dilakukan dengan kolaboratif dan secara garis besar pelaksanaannya dilakukan dengan 4 tahapan yaitu perencanaan, pelaksanaan tindakan, pengamatan, dan refleksi. Penelitian dilaksanakan selama 5 bulan yaitu dari bulan Pebruari sampai dengan bulan Juni 2017 yang melibatkan 2 guru (teman sejawat) untuk membantu mengambil data sebagai observer dalam pelaksanaan penelitian. Subyek penelitian adalah 22 siswa kelas VIII C dengan keadaan siswa heterogen. Penelitian ini dilaksanakan dalam 3 siklus dengan rincian siklus I sebanyak 2 kali tatap muka, siklus II sebanyak 2 kali tatap muka dan siklus III sebanyak 2 kali tatap muka. Materi yang dibahas dalam 3 siklus tersebut adalah sebagai berikut. (1) Siklus I membahas materi menyelesaikan masalah yang berkaitan dengan luas permukaan kubus dan balok; (2) Siklus II membahas materi menyelesaikan masalah yang berkaitan dengan luas permukaan prisma dan limas; dan (3) Siklus III membahas materi menyelesaikan masalah yang berkaitan dengan volume kubus, balok, prisma, dan limas. Adapun teknik analisis data dalam penelitian ini adalah sebagai berikut. (1) Reduksi data, dilakukan dengan memilih data yang sesuai dengan perumusan masalah dari kumpulan data yang ada; (2) Penyajian data, informasi data yang dimiliki disusun secara baik, dan runtut sehingga mudah dilihat, dibaca dan dipahami tentang sesuatu kejadian dan tindakan atau peristiwa dalam bentuk data kuantatif dan data kualitatif; dan 3) Menarik kesimpulan, peneliti mengambil kesimpulan dari data-data yang diperoleh dari berbagai sumber yang masih bersifat sementara sambil mencari data pendukung dan penolakan kesimpulan.

\section{Hasil dan Pembahasan}

Penelitian tindakan ini dilakukan pada kompetensi dasar menghitung luas permukaan dan volume kubus, balok, prisma dan limas, dimana materi yang diberikan berbeda pada tiap siklusnya. Materi yang diberikan pada siklus I yaitu menghitung luas permukaan kubus dan balok dengan bantuan alat peraga benda-benda berbentuk kubus dan balok, pada siklus II materi yang diberikan yaitu luas permukaan prisma dan limas dengan bantuan alat peraga benda-benda berbentuk prisma dan limas, sedangkan siklus III materi yang diberikan adalah menghitung volume kubus, balok, prisma dan limas dengan bantuan benda-benda berbentuk kubus, balok, prisma dan limas ditambah media komputer (power point).

Pada siklus I, pelaksanaan pembelajaran di kelas guru mengalami kesulitan dalam pengelolaan kelas, dikarenakan banyak siswa yang masih kebingungan dengan model pembelajaran yang dilakukan. Hal tersebut menjadi hambatan ketika pembelajaran, karena menyebabkan siswa menjadi kurang konsentrasi di kelas. Ketika guru menanyakan kepada siswa mengenai materi yang belum mereka pahami, hanya sebagian siswa yang bertanya.

Pada siklus II, kesadaran siswa untuk mempelajari materi yang diberikan guru sudah terasa. Hal ini terlihat dari kejujuran siswa ketika mengerjakan tes yang diberikan guru. Perhatian siswa pada saat guru menerangkan juga sudah baik. Siswa menjadi aktif bertanya kepada guru ketika mengalami kesulitan ataupun menjawab pertanyaan dari guru. Keaktifan dan konsentrasi siswa dalam kelompok sudah tampak dan siswa juga sudah percaya diri ketika mempresentasikan hasil diskusi kelompok.

Pada siklus III, kesadaran siswa untuk mempelajari materi yang diberikan guru sudah terbiasa. Hal ini terlihat dari jawaban siswa ketika diberi pertanyaan oleh guru, siswa juga banyak yang bertanya kepada guru ketika mengalami kesulitan dan memiliki sikap percaya diri. Kerjasama dan interaksi siswa dalam kelompok sudah baik, terlihat juga ketika 
mempresentasikan hasil diskusi kelompok siswa mempresentasikan hasil diskusi kelompok mereka dan menuliskannya pada papan tulis, dengan menulis hasil diskusi kelompok di papan tulis siswa dapat mengetahui berbagai alternatif jawaban dalam memecahkan suatu masalah. Tabel 1 berikut menunjukkan rata-rata hasil belajar siswa siklus I sampai dengan siklus III.

Tabel 1. Rata-Rata Hasil Tes Siklus I, II dan Siklus III

\begin{tabular}{lcc}
\hline No & Kegiatan & Rata-Rata \\
\hline $\mathbf{1}$ & Siklus I & 63,64 \\
\hline $\mathbf{2}$ & Siklus II & 68,73 \\
\hline $\mathbf{3}$ & Siklus III & 75,27 \\
\hline
\end{tabular}

Berdasarkan hasil nilai tes tiap siklus dibuat grafik dengan tampilan gambar 1 sebagai berikut.

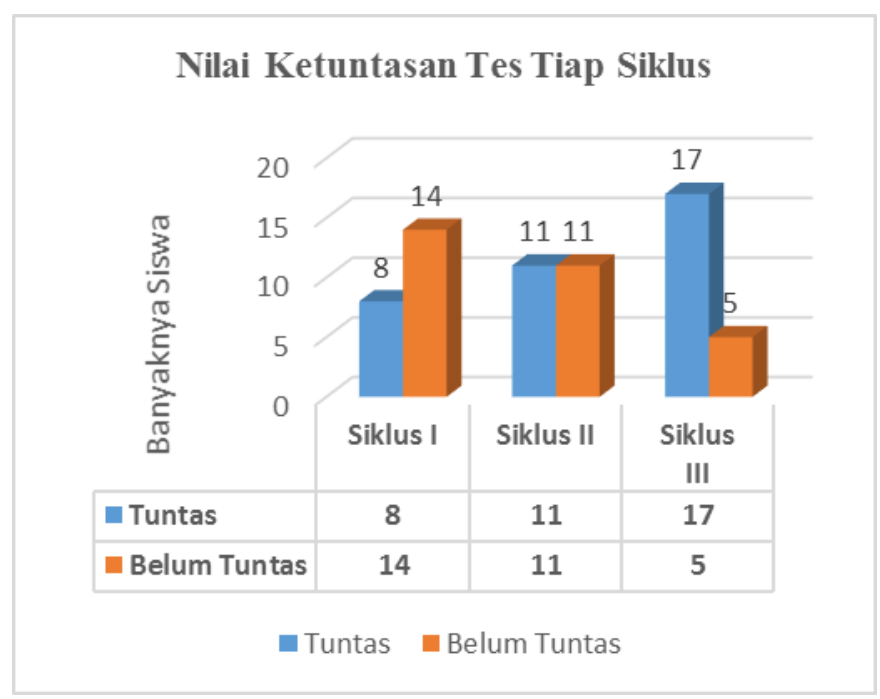

\section{Gambar 1. Diagram Nilai Ketuntasan Tiap Siklus}

Dari penelitian yang telah dilakukan, dengan penerapan model pembelajaran TAI juga menunjukkan adanya peningkatan keterampilan proses siswa kelas VIII C SMPN 4 Sumbang. Hasil penelitian menunjukkan bahwa siklus I siswa yang sangat terampil sebanyak $18 \%$, siklus II sebanyak $45 \%$ dan siklus III sebanyak $55 \%$.

Berdasarkan hasil pengamatan, grafik keterampilan proses siklus 1 sampai dengan siklus 3 dapat dilihat pada gambar 2 berikut. 


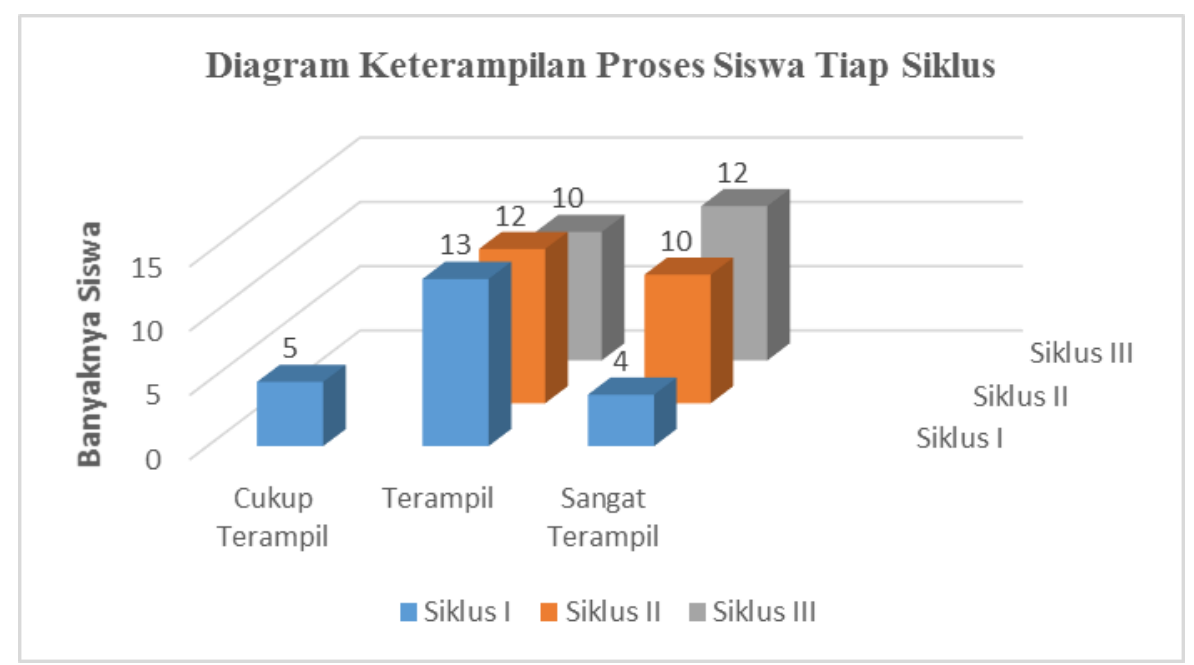

\section{Gambar 2. Diagram Keterampilan Proses Siswa Tiap Siklus}

Hasil pembahasan penelitian dari mulai pengamatan keterampilan proses dan hasil tes belajar siswa, keduanya mengalami peningkatan. Dari penelitian yang telah dilakukan, dengan penerapan model pembelajaran $P j B L$ menunjukkan adanya peningkatan hasil belajar siswa, hal ini sesuai dengan pendapat Ekaputri yang mengatakan bahwa pembelajaran dengan model PjBL mampu meningkatkan motivasi, keaktifan, dan hasil belajar siswa.

Berdasarkan uraian tersebut maka peneliti menyimpulkan bahwa pembelajaran dengan model PjBL dapat meningkatkan keterampilan proses dan hasil belajar siswa, dengan demikian hipotesis dalam penelitian tindakan kelas ini, yang menyatakan bahwa pembelajaran model $P j B L$ pada materi bangun ruang sisi datar menunjukkan peningkatan yang signifikan dan dapat diterima.

\section{Simpulan}

Pembelajaran model Project Based Learning terbukti dapat meningkatkan keterampilan proses pembelajaran matematika pada konsep bangun ruang sisi datar di kelas VIII C. Siswa dengan sungguh-sungguh mengikuti proses pembelajaran mulai dari penyajian kelas, diskusi kelompok, presentasi, penilaian produk, dan presentasi kelompok. Siklus I siswa yang sangat terampil sebanyak $18 \%$, siklus II sebanyak $45 \%$ dan siklus III sebanyak $55 \%$. Pembelajaran model Project Based Learning terbukti dapat meningkatkan hasil belajar pada materi bangun ruang sisi datar di kelas VIII C. Hasil belajar siswa dari tes akhir siklus I sampai dengan tes akhir siklus III mengalami peningkatan dengan rata-rata dari 63,64 pada siklus I menjadi 68,73 pada siklus II, dan meningkat lagi menjadi 75,27 pada akhir siklus III. Siswa diharapkan memiliki andil yang besar dalam proses pembelajaran dengan ikut berperan aktif selama proses pembelajaran, sehingga siswa dapat meningkatkan hasil belajar demi tercapainya tujuan pembelajaran. Peneliti selanjutnya diharapkan lebih teliti dan objektif dalam melakukan pengamatan sehingga diperoleh hasil yang benar-benar mewakili kondisi siswa. 


\section{Daftar Pustaka}

Dalyono, M. (2003). Belajar dan Pembelajaran. Semarang: IKIP Semarang Press.

Depdiknas. (2003). Kurikulum 2004 Sekolah Menengah Pertama. Pedoman Khusus Pengembangan Silabus Berbasis Kompetensi Sekolah Menengah Pertama Mata Pelajaran Matematika. Jakarta: Direktorat Jenderal Perguruan Tinggi Depdiknas.

Dimyati \& Mudjiono. (2013). Belajar dan Pembelajaran. Jakarta: PT. Rineka Cipta.

Ekaputri, D.S. (2012). Penerapan metode Project Based Learning dengan strategi Team Teaching untuk meningkatkan motivasi, keaktifan, dan hasil belajar siswa pada mata pelajaran produktif multimedia di SMK Kompetensi keahlian multimedia. Skripsi. Malang

Hudoyo, H. (2002). Belajar Mengajar Matematika. Jakarta: Depdikbud.

Rais, M. (2010). Project based learning: Inovasi pembelajaran yang berorientasi soft skills. Makalan disajikan sebagai Makalah Pendamping dalam Seminar Nasional Pendidikan Teknologi dan Kejuruan Fakultas Teknik Universitas Negeri Surabaya tahun 2010. Surabaya: Unesa. 